\title{
NORMAS PARA APRESENTAÇÃO DE ARTIGOS
}

Os originais deverão ser redigidos em português, espanhol ou inglês e digitados na fonte Times New Roman tamanho 12, em página tamanho $\mathrm{A} 4$, com espaço 1,5 , alinhado à esquerda e com margem de $3 \mathrm{~cm}$ de cada um dos lados, perfazendo o total de no máximo 17 páginas, incluindo quadros, tabelas e ilustrações.

O encaminhamento dos originais é feito por meio do endereço eletrônico http://revabeno.emnuvens.com.br/revabeno/. A submissão on-line é simples e segura

\section{Tabelas e quadros}

Tabelas e quadros devem ser numeradas consecutivamente em algarismos arábicos, sendo apresentadas em páginas separadas em documento (Word) suplementar intitulado "tabelas" e "quadros". As respectivas legendas deverão ser concisas e localizadas acima da tabela ou quadro. Os mesmos deverão estar formatados de acordo com as especificações técnicas, não sendo aceitas formatações de estilo. Deverão ser indicados os locais no texto para inserção dos quadros e tabelas.

\section{Ilustrações}

As ilustrações (gráficos, desenhos, esquemas, fotografias etc.) deverão ser limitadas ao mínimo indispensável, apresentadas em arquivos separados e numeradas consecutivamente em algarismos arábicos. As respectivas legendas deverão ser concisas, localizadas abaixo e precedidas da numeração correspondente. Deverão ser fornecidas em arquivos formato tif ou jpg, tamanho mínimo 10 x $15 \mathrm{~cm}$ e resolução mínima de 300 dpi. Não serão aceitas ilustrações em Word ou Power Point. Deverão ser indicados os locais no texto para inserção das ilustrações.

\section{A ESTRUTURA DO ORIGINAL}

\section{Carta ao editor}

Deve ser submetida como documento suplementar.

\section{Folha de rosto}

Deve ser submetida como documento suplementar, contendo:

- Título em português, espanhol e inglês, breve e indicativo da exata finalidade do trabalho.

- Nome completo dos autores com a indicação de apenas um título universitário (exemplo: graduando, mestrando ou doutorando em... ou graduado, mestre ou doutor em) e/ou uma vinculação à instituição de ensino ou pesquisa que indique a sua autoridade em relação ao assunto (exemplo: Professor do departamento /faculdade ou curso /sigla da IES).

- Nome, e-mail e endereço completo do autor correspondente.

\section{Resumo, Resumen e Abstract}

Representa a condensação do conteúdo, expondo metodologia, resultados e conclusões, não excedendo 250 palavras. O resumo deve conter:

- Objetivo(s), Metodologia, Resultados e Conclusão, quando o artigo é de pesquisa.

- Objetivo(s), Estratégia de Busca de Artigos e Conclusão, quando o artigo é de revisão.

- Objetivo(s), Relato de Experiência e Considerações Finais, quando o artigo é relato de experiência. A revista adota o formato de resumo não estruturado, ou seja, sem subtítulos. 
Ao final do Resumo, Resumen e Abstract, incluir, respectivamente, os Descritores, Descriptores e Descriptors, Palavras ou expressões (no máximo 5) que identifiquem o conteúdo do artigo. Para sua determinação, consultar a lista de Descritores em Ciências da Saúde - DeCS em http://decs.bvs.br.

\section{Texto}

A estrutura do texto principal varia de acordo com o tipo de artigo:

Artigo de revisão: Introdução, Revisão da Literatura (com Estratégia de Busca de Artigos e Conclusões.

Artigo de relato de experiência: Introdução, Relato de Experiência e Conclusões.

Artigo de pesquisa: Introdução, Metodologia, Resultados, Discussão e Conclusões.

a) Introdução. Deve apresentar com clareza o objetivo do trabalho e sua relação com os outros trabalhos na mesma linha ou área. Extensas revisões de literatura devem ser evitadas e quando possível substituídas por referências aos trabalhos mais recentes, nos quais certos aspectos e revisões já tenham sido apresentados. O objetivo deve constar no último parágrafo da introdução.

b) Metodologia / Materiais e Métodos. A descrição dos métodos usados deve ser suficientemente clara para possibilitar a perfeita compreensão e repetição do trabalho, não sendo extensa. Técnicas já publicadas, a menos que tenham sido modificadas, devem ser apenas citadas.

c) Resultados. Deverão ser apresentados com o mínimo possível de discussão ou interpretação pessoal, acompanhados de tabelas e/ou material ilustrativo adequado, quando necessário. Dados estatísticos devem ser submetidos a análises apropriadas.

d) Discussão. Deve ser restrita ao significado dos dados obtidos, resultados alcançados, relação do conhecimento já existente, sendo evitadas hipóteses não fundamentadas nos resultados.

e) Conclusões. Devem estar de acordo com os objetivos e fundamentadas nos resultados do estudo.

f) Agradecimentos (quando houver).

g) Referências. Para as citações no corpo do texto deve-se utilizar o sistema numérico, no qual são indicados no texto somente os números-índices na forma sobrescrita (antes do ponto ou da vírgula, quando houver). A citação de nomes de autores só é permitida quando estritamente necessária e deve ser acompanhada do ano de publicação entre parênteses e do número-índice. Todas as citações devem ser acompanhadas de sua referência completa e todas as referências devem estar citadas no corpo do texto. A lista de referências deve seguir a ordem em que as mesmas são citadas no texto. A lista de referências deve seguir o Estilo Vancouver, conforme orientações publicadas no site da "National Library of Medicine" (http://www.nlm.nih.gov/bsd/uniform_requirements.html). As abreviaturas dos títulos dos periódicos deverão estar de acordo com o List of Journals Indexed in Index Medicus (http://www.ncbi.nlm.nih.gov/entrez/query .fcgi?db=journals) ou Portal de Revistas Científicas em Ciências da Saúde (http://portal.revistas.bvs.br/). O caractere inicial de cada fragmento deve ser grafado em letra maiúscula e somente o ultimo fragmento deve ser seguido de ponto. Exemplo: Rev Assoc Med Bras. A exatidão das referências é de responsabilidade dos autores. 